\title{
Introduction to the Peer Teacher Training in health professional education supplement series
}

\author{
Annette Burgess ${ }^{1,2^{*}}$, Christie van Diggele ${ }^{2,3}$, Chris Roberts ${ }^{1,2}$ and Craig Mellis ${ }^{4}$
}

\begin{abstract}
Skills in supervision, teaching, facilitation, assessment and feedback, leadership and interprofessional teamwork are required graduate attributes for health professionals. Despite this, the opportunity for learning these skills is rarely embedded within undergraduate and postgraduate health professional training curricula. Additionally, there are limited examples of interprofessional delivery of teaching programs. Since teaching skills can be learned, healthcare faculties play an important role in improving the teaching abilities of their students. At the University of Sydney, we developed and implemented interprofessional, blended learning teacher training programs for health professional students, and junior health professionals: The Peer Teacher Training (PTT) program, and the Clinical Teacher Training (CTT) program. Based on our successful programs, this paper provides an introduction to our Peer Teacher Training supplement. Namely, 11 articles designed to assist those who work and teach in a clinical context; address key challenges; and provide practical tips and frameworks to assist in teaching, assessment, and feedback.
\end{abstract}

Keywords: Peer teacher training, Clinical teacher training, Interprofessional, Feedback, Professional skills

\section{Background}

Teaching is a core professional skill required by all health professionals, from new graduates to experienced clinicians, and academics. Health professionals are not only expected to teach their peers and juniors within their own disciplines, but also across a range of health disciplines. Skills in supervision, teaching, facilitation, assessment and feedback, leadership and interprofessional teamwork are required graduate attributes for health professionals [1-3]. Teacher training programs are not only necessary to prepare health professional students for future practice in the workforce, but also for

\footnotetext{
* Correspondence: annette.burgess@sydney.edu.au

${ }^{1}$ The University of Sydney, Faculty of Medicine and Health, Sydney Medical School, Education Office, The University of Sydney, Edward Ford Building A27, Sydney, NSW 2006, Australia

${ }^{2}$ The University of Sydney, Faculty of Medicine and Health, Sydney Health Professional Education Research Network, The University of Sydney, Sydney, Australia

Full list of author information is available at the end of the article
}

participation in peer assisted learning (PAL) activities that support university curricula. The need for professional development in these areas for healthcare students and junior healthcare practitioners is widely acknowledged. Despite this, the opportunity for learning these skills is rarely embedded within undergraduate and postgraduate health professional training curricula.

\section{What is peer assisted learning (PAL)?}

Peer assisted learning (PAL) is described as "people from similar social groupings who are not professional teachers helping each other to learn and learning themselves by teaching" [4]. As a pedagogy, PAL has the capacity to address specific gaps within curricula [5, 6], and provide qualitatively different experiences to traditional teaching by faculty [4]. Although the vertical integration of health professional curricula provides early patient exposure within clinical settings, the availability of clinicians to teach is a well recognised resource issue $[7,8]$. This

C C The Author(s). 2020 Open Access This article is licensed under a Creative Commons Attribution 4.0 International License, which permits use, sharing, adaptation, distribution and reproduction in any medium or format, as long as you give appropriate credit to the original author(s) and the source, provide a link to the Creative Commons licence, and indicate if changes were made. The images or other third party material in this article are included in the article's Creative Commons licence, unless indicated otherwise in a credit line to the material. If material is not included in the article's Creative Commons licence and your intended use is not permitted by statutory regulation or exceeds the permitted use, you will need to obtain permission directly from the copyright holder. To view a copy of this licence, visit http://creativecommons.org/licenses/by/4.0/ The Creative Commons Public Domain Dedication waiver (http://creativecommons.org/publicdomain/zero/1.0/) applies to the data made available in this article, unless otherwise stated in a credit line to the data. 
highlights the importance of the provision of additional support, including peer assisted learning. PAL activities, including peer teaching, assessment and feedback, are well accepted as support resources in many health curricula, where participation and learning involve a process of socialisation. Some examples of our published PAL activities at the University of Sydney are provided in Table 1 [9-14].

Although reports of formal and informal peer assisted learning activities are aplenty, there is paucity of reports on preparation and training requirements $[15,16]$. For example, a recent systematic review of teacher training programs within the discipline of medicine, found variations in the necessary preparation for peer teaching activities, with little or no assessment of competence prior to participation [15]. However, teaching skills are best acquired through training, opportunities for practice, and provision of specific feedback [16].

Development of the Peer Teacher Training (PTT) program In 2016, we developed an up to date, innovative "Peer Teacher Training" (PTT) program for health professional students [17], based on best practice, and consisting of six modules. This PTT program has been previously described [17]. In 2017, we built on the existing PTT program to develop an eight module "Clinical Teacher Training" (CTT) program targeting junior health professionals [18]. These two programs adopted both an interprofessional and a flipped classroom approach. We had two broad aims; first to promote engagement in the development of learning and teaching, assessment and feedback skills; second, to promote engagement with interprofessional education.

\section{The aim of the Peer Teacher Training supplement}

The aim of this "Peer Teacher Training in health professional education supplement" is to provide theoretical background, insight and tips for health professional students and junior health professionals, based on the experience and implementation of our teacher training programs. Since 2016, our PTT and CTT programs have been used to train over 1000 senior health professional students and staff (including pharmacy, allied health, nursing, dentistry, and medicine). This Supplement is designed to assist those who work and teach in a clinical context, address key challenges and provide practical tips and frameworks to assist in teaching, assessment, and

Table 1 Examples of PAL activities at the University of Sydney

- Senior students as simulated patients in practice OSCE [9]

- Senior students as examiners of their junior peers in practice OSCE

[10]

- Senior students as co-examiners of their peers (alongside academic co-examiners) in formative clinical long case examinations [11-13]

- Senior students as peer tutors in the clinical setting [14]
Table 2 Articles in the Peer Teacher Training in health professional education supplement

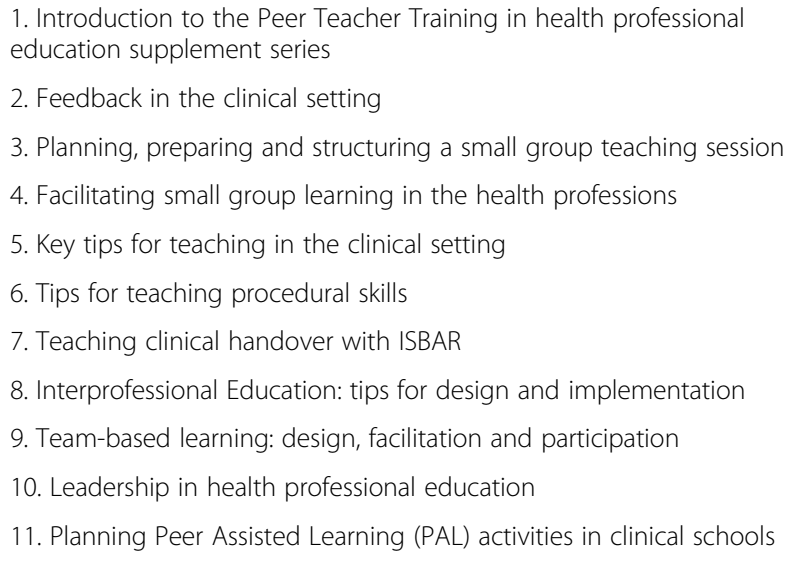

feedback. Although each article is designed to be read individually, there is continuity of themes throughout the Supplement. The title of each article is listed in Table 2, and each article provides theoretical background, practical examples and activities. They are designed as a platform for busy health professional students and junior clinicians to work towards developing skills in communication, teaching, assessment and feedback.

\section{Why the emphasis on interprofessionalism?}

The World Health Organisation (WHO) has identified that effective collaboration between health professionals plays an important role in preparing and providing the health workforce with the ability to respond to local health needs and provide strengthened health systems [19]. Implementation of university health education learning activities within an interprofessional context has the potential to improve patient safety through improvements in leadership skills, collaboration, and communication between healthcare teams [20-22]. However, limited examples of structured interprofessional learning (IPL) activities have been identified within university health professional curricula $[23,24]$. There are obvious barriers to the delivery of interprofessional learning activities, such as timetable restrictions, cultural barriers within organisations, negative attitudes, and the preferred isolation of disciplines (Table 3) [25-27]. We have written these articles and related activities within an interprofessional context, to encourage collaboration between health professional students. We found interprofessionalism to be the most valued feature of both the PTT and CTT programs $[17,18]$. Our students have embraced the rare opportunity for formal collaboration in meaningful activities. Further, faculty, from across disciplines, have enjoyed working together in delivering the programs. We now have a large group of alumni who 
Table 3 Barriers and enablers of IPL

\begin{tabular}{ll}
\hline Potential barriers to IPL & Potential enablers of IPL \\
\hline - Timetabling clashes and restrictions & - Embedding interprofessional activities within curricula \\
- Cultural barriers within organisations and departments & - IPL 'champions' among disciplines \\
- Preference of disciplines to work in their silos & - Leadership in IPL from management \\
- Negative attitudes of faculty and departments & - Enthusiasm towards IPL within organisations \\
- Students' negative attitudes towards professions & - Adequate knowledge and understanding of other professions \\
- Inadequate preparation by participants & - Adequate preparation of learners prior to IPL activities \\
\hline
\end{tabular}

assist in facilitation of the PTT and CTT programs, and the programs are run across a number of hospital and university campuses.

\section{Qualities of effective clinical teachers}

Many of the attributes associated with excellence in role modelling within the healthcare professions relate to teaching skills $[28,29]$. Teaching abilities, dedication to teaching, and an ability to facilitate students' learning needs through rapport, encouragement, and constructive feedback, are all elements that contribute. The extent to which learners are able to engage and learn from clinical tutorials relies on multiple elements, including the planning and structure of tutorials, the attitude of both the teacher and learners, and their mutual understanding of learning outcomes [30]. All learners, including adult learners, have different learning style preferences, and it is important to ensure that teaching styles are flexible enough to accommodate a range of learners. Examples

Table 4 Qualities of effective teachers (adapted from Rose \& Best, 2005) [31]

\begin{tabular}{|c|c|}
\hline Quality & Characteristic \\
\hline $\begin{array}{l}\text { Organisation and } \\
\text { clarity }\end{array}$ & $\begin{array}{l}\text { Explains clearly } \\
\text { Presents material in an organised way } \\
\text { Summarises and emphasises what is important } \\
\text { Communicates what is expected to be learnt }\end{array}$ \\
\hline $\begin{array}{l}\text { Group instruction } \\
\text { skills }\end{array}$ & $\begin{array}{l}\text { Establishes rapport with students } \\
\text { Shows respect for and interest in students }\end{array}$ \\
\hline Enthusiasm & $\begin{array}{l}\text { Is dynamic and energetic } \\
\text { Enjoys teaching } \\
\text { Stimulates interest/curiosity in the subject }\end{array}$ \\
\hline Knowledge & $\begin{array}{l}\text { Is up-to-date with current practice and related } \\
\text { research } \\
\text { Discusses divergent points of view }\end{array}$ \\
\hline $\begin{array}{l}\text { Clinical } \\
\text { supervision }\end{array}$ & $\begin{array}{l}\text { Demonstrates clinical procedures } \\
\text { Provides practice opportunities } \\
\text { Offers professional support and encouragement } \\
\text { Observes student performance } \\
\text { Identifies strengths and limitations objectively } \\
\text { Provides feedback and positive reinforcement }\end{array}$ \\
\hline $\begin{array}{l}\text { Clinical } \\
\text { competence }\end{array}$ & $\begin{array}{l}\text { Demonstrates skill in synthesising and managing } \\
\text { patient problems } \\
\text { Maintains a holistic orientation with patients } \\
\text { Works effectively within a healthcare team }\end{array}$ \\
\hline
\end{tabular}

of qualities of an effective teacher are summarised in Table 4 [31].

\section{Conclusion}

Since teaching skills can be learned, healthcare faculties play an important role in improving the teaching abilities of their students. Development of effective clinical teachers, equipped with optimal teaching strategies should be supported during university education and beyond. This means utilising the best available evidence regarding methods and tools to assist in this endeavour. For busy students, staff and faculty teachers, the success of our PTT and CTT programs $[17,18]$ serves as a model for both "interprofessional" and "flipped" learning designs. Our programs were specifically designed to develop students' knowledge and skills through pre-class preparation, followed by face-to-face class teaching which included; small group teaching, interprofessional activities, and formative assessment with feedback. This Supplement is intended to provide an educational framework upon which students and junior clinicians can build on their competence. We have included instructions in general elements of teaching, and at the same time, provided detailed theory and references for those who wish to explore areas in greater depth.

\section{Abbreviations}

PTT: Peer Teacher Training; CT: Clinical Teacher Training; PAL: Peer Assisted Learning; IPL: Interprofessional learning; OSCE: Objective Structured Clinical Examination; ISBAR: Introduction, Situation, Background, Assessment, Recommendation; WHO: The World Health Organisation

\section{Acknowledgements}

Not applicable.

\section{About this supplement \\ This article has been published as part of BMC Medical Education Volume 20 Supplement 2, 2020: Peer Teacher Training in health professional education. The full contents of the supplement are available online at URL. https:// bmcmedicaleducation.biomedcentral.com/articles/supplements/volume-20- supplement-2.}

\section{Authors' contributions}

$A B, C M, C V D, C R$ contributed to the drafting, and critical review of the manuscript. All authors read and reviewed the final version of the manuscript. The authors read and approved the final manuscript. 


\section{Funding}

No funding was received.

\section{Availability of data and materials}

Not applicable.

\section{Ethics approval and consent to participate}

No ethics approval or consent to participate was required.

\section{Consent for publication}

Not applicable.

\section{Competing interests}

The authors have no competing interests to declare.

\section{Author details}

'The University of Sydney, Faculty of Medicine and Health, Sydney Medical School, Education Office, The University of Sydney, Edward Ford Building A27, Sydney, NSW 2006, Australia. ${ }^{2}$ The University of Sydney, Faculty of Medicine and Health, Sydney Health Professional Education Research Network, The University of Sydney, Sydney, Australia. ${ }^{3}$ The University of Sydney, Faculty of Medicine and Health, The University of Sydney, Sydney, Australia. ${ }^{4}$ The University of Sydney, Faculty of Medicine and Health, Sydney Medical School, Central Clinical School, The University of Sydney, Sydney, Australia

Published: 3 December 2020

\section{References}

1. General Medical Council. Outcomes for graduates; 2018. https://www.gmcuk.org/-/media/documents/dc11326-outcomes-for-graduates-2018_pdf-7504 0796.pdf. Accessed 22 March 2020.

2. Pharmaceutical Society of Australia. National Competency Standards Framework for Pharmacists in Australia. Deakin, ACT; 2016. ISBN: 978-0908185-03-0 (Digital).

3. Australian Medical Council Limited. Standards for Assessment and Accreditation of Primary Medical Programs by the Australian Medical Council 2012. Kingston, ACT; 2012. ISBN 978-1-938182-04-4.

4. Topping KJ. The effectiveness of peer tutoring in further and higher education: a typology and review of the literature. High Educ. 1996;32(3): 321-45.

5. Ten Cate O, Durning S. Dimensions and psychology of peer teaching in medical education. Med Teach. 2007;29(6):564-52.

6. Hurley KF, McKay DW, Scott TM, James BM. The supplemental instruction project: peer devised and delivered tutorials. Med Teach. 2003:25:404-7.

7. Dahlstrom J, Dorai-Raj A, McGill D, Owen C, Tymms K, Watson DA. What motivates senior clinicians to teach medical students? BMC Med Educ. 2005; $5: 27$.

8. Mehta NB, Al H, Young JB, Stoller JK. Just imagine: the new paradigms for medical education. Acad Med. 2013;88(10):1418-23.

9. Burgess A, Clark T, Chapman R, Mellis C. 2013. Medical student experience as simulated patients in the OSCE. Clin Teach. 2013:10:246-50.

10. Burgess A, Clark T, Chapman R, Mellis C. 2013. Senior medical students as peer examiners in an OSCE. Med Teach. 2013:35(1):58-62.

11. Burgess A, Roberts C, Black K, Mellis C. Student ability and learning experience in assessing peers alongside supervisors in the long case. Focus Health Prof Educ. 2015;16(2):27-41.

12. Burgess A, Roberts C, Black K, Mellis C. Senior medical student perceived ability and experience in giving feedback in formative long case examinations. BMC Med Educ. 2013:13:79.

13. Burgess A, Mellis C. Receiving feedback from peers: medical students' perceptions. Clin Teach. 2015;12:203-7.

14. Burgess A, Dornan T, Clarke A, Menezes A, Mellis C. Peer tutoring in a medical school: perceptions of tutors and tutees. BMC Med Educ. 2016; 16:85.

15. Burgess A, McGregor D, Mellis C. Medical students as peer tutors: a systematic review. BMC Med Educ. 2014;14:115.

16. Marton GE, McCullough B, Ramnanan CJ. A review of teaching skills development programmes for medical students. Med Educ. 2015;49(2): 149-60.
17. Burgess A, Roberts $C$, van Diggele $V$, Mellis C. Peer teacher training program: interprofessional and flipped learning. BMC Med Educ. 2017:17:239.

18. Burgess A, van Diggele C, Mellis C. Faculty development for junior health professionals. Clin Teach. 2018;15:1-8.

19. World Health Organisation. Framework for action on interprofessional education and collaborative practice; 2010. http://www.who.int/hrh/ nursing_midwifery/en/. Accessed 13 August 2018.

20. Brock D, Abu-Rish E, Chiu C, et al. Interprofessional education in team communication: working together to improve patient safety. Qual Safety Health Care. 2013;22(5):414-23.

21. Dalton L, Spencer J, Howarth H. Report of the investigation of undergraduate health science student attitudes towards interprofessional education. Hobart: University of Tasmania; 2007.

22. Reeves S, Perrier L, Goldman J, et al. Interprofessional education: effects on professional practice and health care outcomes (update) (review). Cochrane Database Syst Rev. 2013;28:3.

23. Stone J. Moving interprofessional learning forward through formal assessment. Med Educ. 2010:44:393-403.

24. Frenk J, Chen L, Bhutta ZA, Cohen J, Crisp N, Evans T, et al. Health professional for a new century: transforming education to strengthen health systems in an independent world. Lancet. 2010;376:1923-58.

25. Salamonson Y, Everett B, Koch J, Wilson I, Davidson PM. Learning strategies of first year nursing and medical students: a comparative study. Int J Nurs Stud. 2009:46:1541-7.

26. Horsburgh M, Lamdin R, Williamson E. Multiprofessional learning: the attitudes of medical, nursing and pharmacy students to shared learning. Med Educ. 2001;35:876-83.

27. Keshtkaran Z, Sharif F, Rambod M. Students' readiness for and perception of inter-professional learning: a cross-sectional study. Nurse Educ Today. 2014; 34:991-8.

28. Burgess A, Oates K, Goulston K. Role modelling in medical education: the importance of teaching skills. Clin Teach. 2015;12:1-5.

29. Burgess A, Goulston K, Oates K. Role modelling of clinical tutors: a focus group study among medical students. BMC Med Educ. 2015;15(17):1-9.

30. Pitkala K, Mantyranta T. Professional socialisation revised: medical students' own conceptions related to adoption of the future physicians' role - a qualitative study. Med Teach. 2003:25:155-60.

31. Rose $M$, Best $D$. Transforming practice through clinical education, professional supervision and mentoring. Edinburgh: Elsivier Churchill Livingston; 2005.

\section{Publisher's Note}

Springer Nature remains neutral with regard to jurisdictional claims in published maps and institutional affiliations.

Ready to submit your research? Choose BMC and benefit from:

- fast, convenient online submission

- thorough peer review by experienced researchers in your field

- rapid publication on acceptance

- support for research data, including large and complex data types

- gold Open Access which fosters wider collaboration and increased citations

- maximum visibility for your research: over $100 \mathrm{M}$ website views per year

At BMC, research is always in progress.

Learn more biomedcentral.com/submission 